\title{
Development of Extract of Herbal Plants as Anti-Scabies in Pesantren
}

\author{
M L F Kumalasari ${ }^{1}$, A Marwing ${ }^{2}$, E Kususmawati ${ }^{3}$, I Mustika $^{4}, \mathrm{~N} \mathrm{Lusiana}^{5}$, L P Widayanti ${ }^{6}$, \\ F Andiarna $^{7}$, E N Andyarini ${ }^{8}$, S Hidayati ${ }^{9}$ \\ Universitas Islam Negeri (UIN) Sunan Ampel, Surabaya-Jawa Timur, Indonesia ${ }^{1,3,4,5,6,7,8,9}$ \\ Institut Agama Islam Negeri (IAIN) Tulungagung, Tulungagung-Jawa Timur, Indonesia ${ }^{2}$ \\ \{meilina_fitri@uinsby.ac.id ${ }^{1}$, maringarman@gmail.com ${ }^{2}$, ,
}

\begin{abstract}
Many studies in Pesantren have reported a high prevalence of Scabiei (Sarcoptic Mange). However, the public concerns regarding the curative ways of scabies disease commonly focus on chemical medications, such as Permethrin cream (Elimite), Benzyl benzoate, Lindane(gamma benzene hexachloride). The chemical compounds of the medicines are often irritating, unsafe for infants, pregnant, and the elders, as well as the leading resistance of Sarcoptes scabiei mite. Therefore, treatment development is urgently required by utilizing safer materials. Indonesia as a tropical country has many potential medicinal plants that have active compounds against scabies mites. This study is literary research that aims to explore possible medicinal plants possibly embedded in the health culture of pesantren's healing system. The finding of the study shows various of the extract of herbal plants for healing scabies in Pesantren such as seeds and leaves of Azadirachta indica A, leaves of Pluchea indica (L.) Less., roots of Eleusina indica. These compounds resulted in the extract of the seeds, leaves and roots provide resistance to Sarcoptes scabies mites by inhibiting the life cycle of their metamorphosis.
\end{abstract}

Keywords: Scabies, Pesantren, Herbal Plant

\section{Introduction}

Scabies is one type of parasitic infectious disease in the skin caused by the Sarcoptes scabei parasitic microorganism variant hominins. The disease can be transmitted through skin contact to the skin or contact with objects that have been contaminated by mites. Be-sides, scabies can also be transmitted through sexual intercourse [1].

Signs of symptoms that appear as a result of the mite infection are the perceived itching at night. Itching occurs in lesions that can be vesicles, papules and urticaria. Besides, it can also be a bula whose clinical picture is like vesikobular dermatitis. However, in chronic scabies, itching occurs throughout the body. This can lead to uncomfortable feelings, lower productivity and psychosocial problems, such as feeling unacceptable to the environment [2]. 
The world's scabies prevalence ranges from $0.2 \%$ to $71,4 \%$ of the general population, and many occur in countries with a tropical climate [3]. Indonesia is one of the tropical countries with room temperature ranging from $21 \circ \mathrm{C}$ with a relative humidity of $40-80 \%$ to facilitate the development of bacteria, parasites and fungi.

Data from the Ministry of Health RI in 2013 showed the prevalence of scabies in Indonesia, which is $3.9-6 \%$. The prevalence of scabies in Indonesia is now entirely declining from year to year, seen from the data prevalence of $2008 \%-12.96 \%$, and the prevalence year 2009 of $4.912,95 \%[4]$.

The contributing factor of the high prevalence of scabies in Indonesia is the density of occupancy in which a physical contact between individuals facilitates the trans-mission and infestation of scabies [5]. Therefore, the prevalence of high scabies is generally found in environments with a density of occupants and high interpersonal contacts, such as boarding schools [6].

Pesantren is an Islamic school with a boarding system, and its students are called Santri. This institution focuses on providing general but especially Islamic religion [7]. The number of Pesantren in Indonesia in 2019 is as much as 25,938 with 3,962,700 students [8].

Primary infections of scabies do not have a priority because they are not life-threatening. But if this is left, it will cause a secondary infection that is difficult to cure. Secondary infections due to Streptococcus and Staphylococcus may be about the kidneys and cause glomerulonephritis [9].

Management of scabies should be done thoroughly with qualified treatment, such as effective killing at all stages scabies mites, because it does not cause irritation or toxicity. These types of drugs are used, such as sulfur presipitatum, Benzyl benzoate, Permethrin, Krotamiton, and so forth [10]. However, administration of Skabisida in a long term and improper dose will cause the resistance of the mite Sarcoptes scabies against Skabisida [9]. Therefore it is necessary alternative treatment by utilizing natural ingredients that are suspected of having anti scabisida effect.

This natural ingredient is one of the methods of carrying out vector diseases with biological control [11]. Indonesia has a variety of plants with a total of approximately 30,000 species and newly discovered 940 species which can possibly cure diseases, which are referred to as medicinal herbs (11). Indonesian people have long used medicinal plants to cure diseases. Knowledge of the processing of medicinal plants has been inherited hereditary from one generation to the next.

Not much information about the plant extracts used as a scabies therapy. This article will review some research results on scabies therapy with plant extracts that aims to contribute information for seekers Alternative for treating scabies.

\section{Method}

In the review process, we did a data collection technique with study of literature from the library on Scabies therapy by utilizing plant extracts. Data obtained from several research journals and reports of the results of S1/S2 thesis research. The references in Bahasa Indonesia and English ranging from 2013 to 2018 are used with study of libraries using Google Scholar by using the terms "scabies", "Plant extracts", "Scabisida", "Sarcoptes scabiei".

The data is considering plants that have an opportunity to be able to treat scabies and easily obtained. The selection process of the libraries only takes 16 types of plants as data. 


\section{Result and Discussion}

Table 1. Plants with Antiskabies Activity

\begin{tabular}{|c|c|c|c|c|}
\hline No & Latin Name & Local Name & Family & Part Plant \\
\hline 1. & aloe vera & lidah buaya & Xanthorrhoeaceae & Leaves \\
\hline 2. & Azadirachta indica & Mimba & Meliaceae & Seed \\
\hline 3. & Azadirachta indica & Mimba & Meliaceae & Leaves \\
\hline 4. & Aegle marmelos & bila/maja & Rutaceae & Fruit meat \\
\hline 5. & Eleusina indica & $\begin{array}{l}\text { Pata/ rumput } \\
\text { belulang }\end{array}$ & Poaceae & Root \\
\hline 6. & Imperata cylindrica & $\begin{array}{l}\text { alang- } \\
\text { alang/takengon }\end{array}$ & Poaceae & Flower \\
\hline 7. & Melaleuca alternifolia & tea tree & Myrtaceae & Oil \\
\hline 8. & Mangifera indica & Manga & Anacardiaceae & Leather stem \\
\hline 9. & Piper bettle & Sirih & Piperaceae & Leaves \\
\hline 10. & Areca catechu & Pinang & Arecaceae & Seed \\
\hline 11. & Curcuma aeruginosa & temu hitam & Zingiberaceae & Rhizome \\
\hline 12. & Curcuma heyneana & temu giring & Zingiberaceae & Rhizome \\
\hline 13. & Kaempferia rotunda & $\begin{array}{l}\text { temu putri (temu } \\
\text { putih) }\end{array}$ & Zingiber & Rhizome \\
\hline 14. & Languas galanga & Lengkuas & Zingiberaceae & Rhizome \\
\hline 15. & Pluchea indica & Beluntas & Asteraceae & Leaves \\
\hline 16. & Tinospora tuberculata & Bratawali & Menispermeaceae & Leaves \\
\hline
\end{tabular}

Herbal medicine derived from plants becomes an alternative in treating scabies disease. This herbal treatment is done to avoid the side effects of antiskabisida chemical medications. Some plants have been extracted with dosages and specific ways have been shown to have antiscabisida activity.

Aloe vera Gel is a gel contained in the herbal plant. It is white and transparent with substances, such as saponin, Anthraquinone, Anthrax Zero, Aloeemodin, Anthracenesinamat, chrysophanic acid, eteraloin resistanol, acid Amino, oxidase enzyme, catalase, lipase, minerals, and hormones[12]. Antrakuinon has the mechanism of dena-tured protein cell SHG, providing a damaging effect for mites. Saponin has the ability as an antiseptic \& spur collagen differentiations so that it is adequate to heal open wounds. While flavonoids serve as antibacterial, antioxidant, and can inhibit bleeding on the skin [13].

Mimba seeds can be used as scabies therapy by Zainal's research in 2013 which is why the introduction of the cream from the extract $10 \%$ of Mimba seeds can treat clinically scabies [14]. Murniati in 2018 also researched that by utilizing Mimba leaves as soaps in scabies, it can accelerate the healing of scabies wounds [15].

Mimba has an active ingredient in the form of Azadirachtin, which is an anti feedant by producing a specific stimulant in the form of chemical receptors on the mouth that work together with the chemical receptors in disrupting the perception of stimulation to eat (phagostimulant). The secondary effect of Azadirachtin contained Mimba acts as an ecdysone blocker or substance that may inhibit the work of the ecdysone hormone, i.e. a hormone that functions in the process of the insect metamorphose [16].

The research from Fatma Sari in 2016 mentions that the skin of flesh that is applied to the skin can help with the healing of scabies. Maja has an active compound that serves as an antibacterial. This compound interferes with microbe metabolism[17] 
Besides, Pata can also help to cure scabies wounds by utilizing the roots. The roots are washed and wrapped with banana leaves, then tied on the affected skin [17]. The active compounds in this plant are antihistamines and anti-inflammatory. Antihistamines work in the sense of itching and anti-inflammatory pain can relieve inflammation of the skin.

Alang-Alang crops can be used to accelerate the healing of scabies wounds by utilizing parts of the flowers. Scabies therapy is done by mashing an old flower and applied to the skin [18]. Compounds easily found in the reeds has function as an antibacterial that can improve the wound healing process by eliminating bacteria whichplay a role in the inflammatory process.

The Tea tree oil contains anti-inflammatory, antibacterial and anti pruriticcompound. This compound will help accelerate the healing of scabies wounds [19].

The rubber on the leather stem of the manga plant contains active compounds of saponins and flavonoids as an anti-inflammatory to accelerate the process of wound healing in scabies[20]. Besides, it serves as an analgesic to reduce the discomfort of scabies wounds. Saponin also has the ability as an antiseptic and can spur collagen differentiations so that it is useful to heal open wounds. While flavonoids serve as antibacterial, antioxidant, and can inhibit skin bleeding

Elly examined some plants for medicine, among them betel leaf and areca nut. Betel Leaf has an active anti-bacterial compound that can inhibit the expansion of scabies wounds and help the healing of the injury [21]. While contains tannins, flavonoids and alkaloids that can serve as antibacterial.

Familia Zingiberaceae has several species that can be beneficial for the treatment of scabies. Research from Sylvia U.T. Pratiwi in 2015 mentions C. aeruginosa species Roxb (Black Temu), C. Heyneana Val. \& V. ZIJP (Temu giring), Kaempferia rotunda L. (The princess's inventiveness) and Languas Galanga (L.) Stuntz (galangal) can cure scabies wounds that Utilize the rhizome part. This herb contains anti-inflammatory compounds that are beneficial for the treatment of scabies wounds. Besides, it also serves antipyretic and analgesic, which can reduce the discomfort use due to itching[22].

Sylvia also mentions that Beluntas and the Bratawali leaves can also help the healing of scabies. Beluntas contain active compounds of flavonoids, essential oils and alkaloids, so they can act as an antibacterial and anti-inflammatory exhibits. Meanwhile, Bratawali contains active compounds of flavonoids, alkaloids and saponins that also serve as an antibacterial which accelerates wound healing [22].

\section{Conclusion}

There are many herbs efficiently become anti scabies with various content that is potential as an alternative medicine due to drug resistance anti scabies synthesis. This compound provides resistance to Sarcoptes scabiei mites by inhibiting the life cycle of the mite metamorphosis.

\section{References}

[1] M. Stanhope and R. Knollmueller, Praktek keperawatan kesehatan komunitas. Jakarta: EGC, 2010.

[2] Siregar, Atlas Berwarna Saripati Penyakit Kulit. Jakarta: EGC, 2014.

[3] D. K. Yeoh, A. C. Bowen, and J. R. Carapetis, "Impetigo and scabies - Disease 
burden and modern treatment strategies," J. Infect., vol. 72, pp. S61-S67, Jul. 2016.

[4] V. Ediasari, "Hubungan status gizi santri dan pesonal hygiene dengan kejadian Skabies pada santri pondok pesantren Darussalam di kabupaten Tebo tahun 2016.," 2016. .

[5] P. Johnstone and M. Strong, "Scabies," BMJ, vol. 8, 2008.

[6] A. F. Ratnasari and S. Sungkar, "Prevalensi Skabies dan Faktor-faktor yang Berhubungan di Pesantren X, Jakarta Timur," vol. 2, no. 1, p. 6, 2014.

[7] S. Haningsih, "Peran strategis pesantren, madrasah, dan sekokah Islam di Indonesia," El Tarbawi J. Pendidik. Islam, vol. 1, no. 1, 2008.

[8] Kemenag RI, "Statistik Pesantren," 2019.

[9] J. Heukelbach, T. Wilcke, B. Winter, and H. Feldmeier, "Epidemiology and morbidity of scabies and pediculosis capitis in resource-poor communities in Brazil," $\mathrm{Br} . J$. Dermatol., vol. 153, no. 1, pp. 150-156, Jul. 2005.

[10] K. Karthikeyan, "Treatment of scabies: newer perspectives," Postgrad. Med. J., vol. 81, no. 951, pp. 7-11, Jan. 2005.

[11] World Health Organization, Ed., Handbook for integrated vector management. Geneva: World Health Organization, 2012.

[12] B. Purwanto, Herbal dan keperawatan komplementer (teori, praktik, hokum dalam asuhan keperawatan). Yogyakarta: Nuha Medika, 2013.

[13] N. Aqidah, A. Nuraeni, and M. Supriyono, "PENGARUH SKIN CARE DAN GEL ALOEVERA TERHADAP PENYEMBUHAN LUKA SCABIES PADA REMAJA DI PONDOK PESANTREN AZIZIYYAH NGALIYAN," Karya Tulis Ilm. STIKES Telogorejo, p. 15, 2017.

[14] N. Zainal, F. Tabri, S. V. Muchtar, and K. Djawad, "EFEKTIVITAS KRIM EKSTRAK BIJI MIMBA 10\% PADA PENDERITA SKABIES,”p. 7, 2013.

[15] A. Murniati and I. Rohmawati, "The Influence Of Using Extract Neem Leaf (Azadirachta indica A.juss) Soap In The Scabies lesions grade II Healing," $J$. Agromedicine Med. Sci., vol. 4, no. 3, p. 140, 2018.

[16] A. S. Aradilla, "Uji Efektifitas Larvasida Ekstrak Ethanol Daun Mimba (Azadirachta indica) Terhadap Larva Aedes aegepty," p. 64, 2009.

[17] F. S. Siharis and I. Fidrianny, "ETNOFARMAKOLOGI DAN UJI AKTIVITAS SALAH SATU TUMBUHAN YANG DITEMUKAN DI SUKU MORONENE TOBU HUKAEA LAEA KABUPATEN BOMBANA SULAWESI TENGGARA," vol. 1, p. 9, 2016.

[18] S. Hidayat and A. N. Rachmadiyanto, "Utilization of Alang-Alang (Imperata cylindrica (L.) Raeusch.) as Traditional Medicine in Indonesian Archipelago,” p. 8, 2017.

[19] J. Thomas et al., "Therapeutic Potential of Tea Tree Oil for Scabies," Am. J. Trop. Med. Hyg., vol. 94, no. 2, pp. 258-266, 2016.

[20] M. Khushtar, "NUTRITIONAL IMPORTANCE AND PHARMACOLOGICAL ACTIVITY OF MANGIFERA INDICA,” World J. Pharm. Pharm. Sci., pp. 258-273, May 2017.

[21] E. Purwanti and T. Mulyatin, "Ethnobotany Medicinal Plants For Local Community in Southwest Sumba District," in Proceedings of the 5th International Conference on Community Development (AMCA 2018), 2018.

[22] S. U. P. Ellen L Lagendijk, “Antimicrobial effects of Indonesian Medicinal Plants Extracts on Planktonic and Biofilm Growth of Pseudomonas aeruginosa and Staphylococcus aureus," J. Hortic., vol. 2, no. 1, 2015. 
